Journal of Teacher Education for Sustainability, vol. 13, no. 2, pp. 17-43, 2011

\title{
SCRUTINIZING THE EXPLICIT, THE IMPLICIT AND THE UNSUSTAINABLE: A MODEL FOR HOLISTIC TRANSFORMATION OF A COURSE FOR SUSTAINABILITY
}

\author{
Cosette Armstrong \\ Oklahoma State University, the United States of America \\ Melody LeHew \\ Kansas State University, the United States of America
}

\begin{abstract}
The purpose of this qualitative case study is to describe the development and implementation of a model for course redevelopment for education for sustainable development (ESD). The theoretical approaches to curriculum development of Ralph Tyler (1949) and Elliot Eisner (2002) were influential in the development of the model. The Tyler Rationale (Tyler, 1949) provided general scaffolding for the process and was particularly useful for the development of learning outcomes, while the philosophy of Eisner (2002), complementary to the tenets of ESD, was instrumental in designing classroom experiences to deliver the learning outcomes. Importantly, the model provides a way to empower the individual educator to integrate ESD at the course level as well as a useful mechanism to ensure the holistic application of ESD, aligning sustainability with the predilections of any discipline. This paper demonstrates the use of the model to redevelop an apparel product development course, reframing it for sustainability and sustainable development. The new course was piloted and has now been offered twice since its inception, resulting in a positive students' learning experience.
\end{abstract}

Key words: sustainability, curriculum, model, sustainable development, transformation

\section{Introduction}

Though UNESCO's decade for education for sustainable development (ESD) has yielded a tremendous progress in the way of campus greening and research initiatives, progress has lagged in the areas of pedagogical innovation and curriculum redevelopment (Sterling \& Scott, 2008; Cotton, Bailey, Warren, \& Bissell, 2009; de le Harpe \& Thomas, 2009), especially in higher education (Bosselmann, 2001; Everett, 2008; Rode \& Michelsen, 2008). A primary impediment to the integration of ESD is the highly specialised nature of academic 
disciplines (Jucker, 2002; Calder \& Clugston, 2003; Haigh, 2005; Moore, 2005; Everett, 2008). For instance, in the textiles and apparel (TA) field in which we work, academicians reflect a wide range of foundational preparation (for instance, anthropology, psychology, history, chemistry) with diverse specialisations (for instance, merchandising, marketing, design, textiles), varying widely in curricular priorities. This kaleidoscopic milieu, common in many applied science disciplines like TA, often constrains consensus about what is important in education, making a transformation across the entire curriculum seemingly impossible. Nevertheless, educators are increasingly under pressure to integrate sustainability into the courses they teach.

In recent years, the typical approach used to integrate sustainability into the TA curriculum and many other disciplines has been to treat the concept as an extra topic; adding a lecture, module, or course to the curriculum. But, Sterling (2004) argues that this strategy lacks an epistemological foundation oriented to sustainability. The nature of sustainability often conflicts with traditional course content, which Bowers (2001) argues may contain language embodying root metaphors like anthropocentrism, unlimited growth, patriarchy and individualism that perpetuate unsustainable cultural patterns. When these root metaphors dominate a discipline, the ability to identify and adopt new, more ecologically sound understanding is diminished significantly. Thus, when sustainability is integrated in a fragmented way rather than systemically, a dichotomy emerges, causing the learner to feel as though they are being pulled in two very different directions. Jucker (2004) argues that integrating sustainability requires a clear understanding of the dominant ideologies that fuel unsustainability. What we do as educators, both explicitly and implicitly, must be scrutinised to a far greater degree, rooting out the unsustainable.

Currently, there is a need to empower individual educators to make change at the course level, even if an organised effort to address the entire curriculum is not yet possible. There is also a need for mechanisms by which discipline-specific content can be reframed with the philosophy of sustainability. The purpose of this descriptive case study was to develop and implement a process to address these needs. A model was developed to provide a mechanism to create symbioses between ESD and the predilections of any discipline. The development of the model and how it was used to redevelop a TA course are both described.

\section{Research context and design}

The current project evolved as an inescapable step in a larger exploratory case study. In the larger study, a TA course was to be redeveloped according to the ESD framework, implemented and utilised to examine a comparison between the learning and development experience of students in the new course to other courses in the same programme. But, no structure existed to ensure the course's alignment with ESD, and, therefore, the quality of the treatment for the larger case would depend on a firm theoretical and systematic approach to its development. Responsively, the researchers organised a qualitative descriptive case study designed to accomplish this preliminary phase of their research. Taking into consideration the aforementioned challenges above, the researchers were guided by two 
primary research questions: What is the process by which an educator may redevelop a single course for ESD? How might an educator be held accountable to the ESD framework during the course redevelopment process?

Case studies are ideal for generating a deep description and understanding of a real-life situation, event or process as perceived by those who are involved (Yin, 1989; Stake, 1995; Merriam, 1998). This research design is well poised for applied fields like education as they often lend themselves to solving practical problems, such as those outlined in this paper. Case studies are not necessarily used to generate hypotheses or build theory, but simply aim to offer a descriptive account, though most are supported by a theoretical framework or concept (Yin, 1989; Merriam, 1998).

In the current case, the researchers developed a theoretical model for the course redevelopment, utilising the work of curriculum development theorists. Then, the model was implemented. During implementation, the researchers documented all activities conducted, including a series of content analyses and decision-making exercises. The first author coordinated the project, while the second author served as a peer debriefer. Creswell (2007) recommends the use of peer debriefing to strengthen the credibility and validity of qualitative research by allowing an external party, unattached to the outcomes of the study, to review the researcher's inquiry practices and processes.

The project was conducted in a TA programme at a large land grant university in the Mid-west where both researchers (the authors) held teaching assignments. The TA programme was similar in size to other like programmes in the U.S., with an average enrolment of approximately 250 undergraduate students and 50 graduate students (resident and distance). At the time of this case study, the programme had experienced some integration of sustainability topics into some courses, but had not been the subject of a curriculum redevelopment initiative, making it an ideal context for this project.

The course selected for redevelopment was entitled Private Label Apparel Product Development, a senior-level capstone course and a programme requirement for both TA design and marketing specialisations. This course was ideal for redevelopment for several reasons. Firstly, senior-level undergraduates, nearing the end of their programme, were in the best position to contrast their experience in the new course to that of other courses in their programme for the purpose of the larger exploratory case study. Secondly, sustainability challenges in the apparel industry span the product development process from materials selection to consumer use to disposal. This attribute made the course ripe for the integration of sustainability concepts. The opportunities to reframe content for sustainability were evident at virtually every stage of the course. Thirdly, the course was a model scenario for the integration of collaborative and thinking skills considered fundamental to the ESD framework, as the course had been characterised by low enrolment and collaborative work.

\section{Ralph Tyler meets Elliot Eisner}

Through a survey of curriculum development theory conducted by the researchers, two approaches became highly influential in the current case: the Tyler Rationale by Ralph Tyler (1949), presented in the Basic Principles of Curriculum and Instruction, and Elliot Eis- 
ner's (2002) approach, presented in The Educational Imagination. Many curriculum development models emerged in the early 1900's to guide educational planning and evaluation in response to dramatic societal changes. Historically, faculty psychology theory dominated curriculum paradigms; the purpose of education thought to exercise the brain like a muscle through memorisation and recitation with an emphasis on mastery of subject matter. The Tyler Rationale (Tyler, 1949) countered this paradigm, offering a structured, mostly linear framework for developing curriculum to achieve the student's developmental needs and societal needs as well as priorities of the subject matter (Pinar, Reynolds, Slattery, \& Taubman, 1995). Eisner's (2002) approach, originally published in 1979, was developed during the 1960's Reconceptualisation of Education, a movement which questioned the viability of structure and systematic process in educational design altogether; advocating instead for flexibility, variety and, most importantly, imagination. Admittedly, the two authors occupy polar positions on a continuum; Tyler (1949) emphasising the planned curriculum, a preoccupation with outcomes, Eisner (2002) emphasising the enacted and experienced curriculum, a preoccupation with the process. In the current case, these distinctive strengths were both utilised to generate a model for course redevelopment for ESD.

\section{The Tyler rationale}

Easily one of the most recognised curriculum development models (Pinar et al., 1995; Marsh \& Willis, 2007; Oliva, 2009), American curriculum developers once flocked to the Tyler rationale; as most reform movements in the US have promoted an outcomes-based educational system (Marsh \& Willis, 2007). The Tyler Rationale (Tyler, 1949) emphasises planning: planning the purpose of education, planning educational experiences to support that purpose and planning for the evaluation of the outcomes. His approach consists of four primary steps.

1. The educational purpose is determined. Tyler suggests assessing the needs and interests of the learner, the needs of the local community and society and the priorities of a specific subject matter through primary data collection exercises, such as interviews with students, studies of contemporary life or consultation with subject specialists. Learning outcomes are derived from this data which can reasonably be accomplished through education. These outcomes are then screened to align with a desired educational philosophy (the purpose of education) and a preferred educational psychology (how people learn best).

2. Learning experiences are selected in accordance with the precisely defined set of learning outcomes. Meaning, experiences are designed to deliver a predicted outcome.

3. Learning experiences are organised. Three primary organisational tenets are used: continuity, sequence and integration; positioning outcomes to be revisited throughout a learner's educational experience, graduating sequentially and successively and integrated to relate to other levels of the same content area as well as different content areas. Then, specific lessons, topics or units and the time period for which they will be implemented are planned. 
4. A plan to evaluate the delivery of learning outcomes is formed. Accordingly, the learning outcomes are used to guide selection of appropriate evaluation methods. Further, outcomes are stated in a way that is indicative of how they will be measured.

Tyler's approach has been heavily criticised among curriculum theorists for its linear, systematic and outcomes-based approach and the many unintended consequences that have manifested through its use (Marsh \& Willis, 2007). In fact, Tyler's penchant for organisation, precision and measurement departs the philosophy of ESD, which seems to emphasise a more qualitative approach to sustainability education (UNESCO, 2005). Nevertheless, this process offers an important structure for educators who may not receive their training in a college of education and have little foundational knowledge of curriculum development. Specifically, the first step of this approach was most influential in the current project, particularly the research and organisation used to identify key learning outcomes and screen them to align with the educational philosophy and psychology of ESD.

\section{Eisner's educational imagination}

While the Tyler Rationale (Tyler, 1949) contributed to an important beginning for the course redevelopment model, the addition of Eisner was necessary for portions of the model which affected the student experience, such as learning experiences and assessment, as Eisner's philosophy more closely aligns with ESD. Eisner is a constructivist, chiefly influenced by John Dewey and the predilections of the Progressive Era of Education. Pronounced in Eisner's work (1967, 1998, 2001, 2002) is his opposition to the standardisation and operationalisation of education, roots found in reform movements like the Progressive Era of Education in the 1930's, the Reconceptualisation of education in the 1960's (Pinar et al., 1995) as well as ESD (Foster, 2002; Orr, 2003; Haigh, 2008). Unlike Tyler's (1949) preoccupation with outcome measurement as the key indicator of quality in education, Eisner (1998) advocates for the study of how students experience education, paying attention to the context of educational situations to glean its quality. Eisner (2002) bristles at curriculum changes made in the name of efficiency, which may marginalise some learners. Rather, he emphasises responsiveness of curriculum to the context of the learner: who they are, where they are, what resources are available to them, etc.; while Tyler emphasises a more equal consideration of the needs of students, society and subject.

Eisner (2002) also advocates for transparency of the explicit, implicit and null curriculum (what is not taught at all) during the curriculum development process. By continually scrutinising the ideologies that dominate the explicit, implicit and null curriculum, more holistic decisions can be made, a sentiment shared by ESD authors (Jucker, 2004). Ideologies are sometimes explicit, but mostly implicit or embodied in what is missing entirely, and, to the degree this goes unnoticed, meaningful educational change is inconceivable. This tenet was a chief consideration in the current project.

Eisner's (2002) approach includes seven elements he felt were important for curriculum developers to consider. Unlike the linear nature of the Tyler Rationale (Tyler, 1949), Eisner felt that the following considerations could be taken at any time and in any order. 
1. Goals and priorities are identified. Eisner disparaged Tyler for his conjecture that the most compelling educational outcomes always follow precisely stated goals. Rather, Eisner felt explicitly stated outcomes could be enhanced by including other more expressive outcomes that are not as rigidly defined. As such, performances of students are not planned to a predictive degree, but are crafted with ample room for emergent outcomes; outcomes that may expand, or even change, the educational goals. He also contends that values, intentions and future-mindedness should be central in planning educational aims, rather than aiming only for what can be easily measured.

2. Content is created. Eisner advocates that though there may be a variety of concepts considered important in a subject area, many are equally sufficient to helping the learner meet and extend the educational goals. Importantly, during the selection of this content, scrutiny is given to what is explicit in this content, what may be implicitly embodied in these messages or behaviour as well as what may be missing entirely.

3. Learning opportunities are crafted. While Tyler emphasises experiences designed to deliver predicted outcomes, Eisner describes learning opportunities as a vehicle to transform the goals. Crafting such events requires imagination and artistry of teachers, another critical departure from Tyler, who was partial to subject specialists. Eisner is partial to high levels of student engagement in these events, rather than a sole focus on the subject matter.

4. Learning opportunities are organised. Eisner recommends a spider web approach to organisation for learning opportunities, opposing Tyler's stair case model, which leaves little room for exploration or accidental discoveries. Rather, curriculum organisation takes the form of projects, activities or materials designed to solicit engagement and action. This offers the learner the opportunity to develop ideas and skills which vary among peers, while the teacher facilitates the interests and goals of the learner.

5. Content areas are organised. Eisner acknowledges that most disciplines embody a structure passed down by tradition which is often difficult to abandon. However, at the least, he emphasises the need to demonstrate strong relationship among content areas across the curriculum without evidencing the predictive scaffold evident in Tyler's model.

6. Variety in modes of presentation and response is invited. The consideration of how learning opportunities are presented to the learner and how students are permitted to express what they are learning, is virtually absent from Tyler's approach. Traditionally, modes of presentation and response have been verbal and written only, modes which may not accommodate diverse learning and communication styles. Eisner champions for variety in how concepts are delivered by the educator as well as how learning is communicated by the student.

7. Assessment procedures are developed concurrently. According to Eisner, decisions about assessment are made throughout the curriculum decision-making process, not as a separate function at the end, as implied by Tyler. Not a fan of scientific measurement, Eisner encourages the use of authentic assessment, forms of 
evaluation that speak to how a learner arrives at an outcome, rather than an outcome's measurement. These types of appraisal become a learning opportunity, serving the learner in some way. Eisner argues that these approaches better prepare the learner for life outside school by increasing lifelong learning attitudes and promoting retention and understanding.

Eisner (2002) believes that desired outcomes consistent with a specific discipline are important, but the process or journey of getting there should hold equal priority, a key attribute which aligns with ESD. He admits that his approach commands the most from practitioners, as they must intuit emergent outcomes, becoming intimately acquainted with learners' needs, and remain flexible to provide resources customised to individual journeys. They must also exert more energy when assessing these journeys. But, Eisner argues that the use of his model signals to the learner what is most valuable in their development. In sum, Tyler's approach was utilised to anchor the process of developing learning outcomes and Eisner's approach was used to poise the learning outcomes for expansion.

\section{Developing the model: Why Tyler and Eisner?}

On the surface, the approaches of Tyler (1949) and Eisner (2002) converge on many of the same factors (Table 1). Both agree that decision-making must largely centre on the articulation of desired educational goals, the planning and organisation of experiences that may allow learners to meet those goals and an evaluation plan that speaks to the quality of the educational programme. From there, the philosophies of Tyler and Eisner diverge remarkably (Table 2). Arguably, the Tyler Rationale (Tyler, 1949) reads like directions to a puzzle in contrast with the dynamic educational journey Eisner describes. Indeed, Tyler favours linearity, prediction, pedagogical control and quantitative evaluation, while Eisner promotes the antithesis, advocating for an artistic approach to curriculum which is highly iterative and nonlinear. Interestingly, both theorists have been criticised for their approaches; Tyler for his linear and prescriptive nature and Eisner for his flexibility and lack of specificity (Marsh \& Willis, 2007). Nevertheless, the opposition of their philosophies was inconsequential here, as it was these specific attributes, Tyler's linearity and structure and Eisner's flexibility and creativity, which made notable contributions to the course redevelopment model, offering enough structure and guidance of the curriculum development process for educators who may not be trained in education, and at the same time, being responsive to the pedagogical philosophy of ESD which is connoted by high levels of social interaction and unpredictable emergent outcomes which result from that interaction (Ellis \& Weekes, 2008; Sipos, Battisi, \& Grimm, 2008; Svanström, Lozano-Garcia, \& Rowe, 2008). 
Table 1. The Tyler rationale and Eisner's educational imagination

\begin{tabular}{cc}
\hline Tyler (1949) & Eisner (2002) \\
\hline Decide on the educational purpose & Goals and priorities \\
What educational purposes should the school & explicit + less rigidly defined; \\
seek to attain? & allow ample time for deliberation \\
Select learning experiences & Content of the curriculum \\
How can learning experiences be selected & explore content options; \\
that are likely to be useful in attaining these & scrutinise explicit, implicit and null curricu- \\
outcomes? & lum \\
Organise learning experiences & Types of learning opportunities \\
How can learning experiences be organised & seek transformative goals meaningful to \\
for effective instruction? & students \\
Plan for evaluation & Organisation of learning opportunities \\
How can the effectiveness of learning ex- & nonlinear approach; \\
periences be evaluated? & expansion and extension of outcomes wel- \\
& comed \\
& Organisation of content areas \\
& a particular emphasis placed on an entire \\
& curriculum \\
& Mode of presentation \& mode of response \\
& a variety of modes extend opportunities for \\
& students \\
& Types of assessment procedures \\
& a broad range of methods administered at \\
& multiple stages \\
\hline
\end{tabular}

Specifically, the structure offered in the collection and analysis of various types of information (about students, society and the subject) and the systematic screening of that information to derive learning outcomes relevant to the educational philosophy and psychology were characteristics well poised to offer the needed mechanism to reframe discipline specific content to align with the epistemology of ESD. Also, as Eisner was more focused on being responsive to learners in the development of educational goals, and ESD places particular emphasis on the achievement of societal needs, Tyler's approach to developing learning outcomes across the three types of information seemed more thorough and balanced. Notably, though Tyler anchored the learning outcome development phase of the model, Eisner's philosophy was considered in this phase to ensure learning outcomes were stated broadly, leaving room for emergent outcomes.

Table 2. Tyler and Eisner compared

\begin{tabular}{lll}
\hline Author & Tyler (1949) & Eisner (2002) \\
\hline curriculum development process & linear, structured, systematic & $\begin{array}{l}\text { uncertain, complex, flexible, } \\
\text { iterative, artistic }\end{array}$ \\
\hline favoured curriculum developer & subject specialist & practitioner \\
\hline $\begin{array}{l}\text { learning outcomes } \\
\text { goal of learning experiences }\end{array}$ & $\begin{array}{l}\text { frecise, predictable; designed } \\
\text { for measurement }\end{array}$ & $\begin{array}{l}\text { some explicit, some expressive; } \\
\text { outcome delivery }\end{array}$ \\
$\begin{array}{l}\text { organisation of learning experi- } \\
\text { ences }\end{array}$ & linear & emergent outcomes \\
\hline
\end{tabular}


Sequel to Table 2.

\begin{tabular}{lll}
\hline $\begin{array}{l}\text { nature of evaluation or assess- } \\
\text { ment methods }\end{array}$ & quantitative & qualitative \\
\hline $\begin{array}{l}\text { purpose of evaluation or assess- } \\
\text { ment }\end{array}$ & $\begin{array}{l}\text { measurement of quality of edu- } \\
\text { cation and areas of deficiency }\end{array}$ & $\begin{array}{l}\text { description of students' experi- } \\
\text { ence }\end{array}$ \\
\hline nature of curriculum & prescriptive & responsive to local context \\
\hline
\end{tabular}

Eisner's (2002) approach, on the other hand, was especially useful for the planning and organisation of learning experiences as well as decisions related to assessment, as his philosophy is especially compatible with ESD, particularly his opposition to standardisation and efficiency in education as well as the scrutiny of dominant ideologies that manifest in curriculum decisions (Foster, 2002; Orr, 2003; Rees, 2003; Haigh, 2008). Eisner’s attention to the implicit and null curriculum aligns with ESD authors like David Orr (2004) who argue that how we teach is just as important as what we teach, especially when it comes to sustainability. Undoubtedly, Eisner's sensitivity to the values-laden nature of curriculum development is responsive to ESD. His embrace of ambiguity and complexity in curriculum development is also akin to how ESD authors have characterised the holistic integration of sustainability (Landorf, Doscher, \& Rocco, 2008; Sterling \& Scott, 2008). Further, Eisner’s artistic approach to crafting educational opportunities responsive to local contexts easily translates to ESD (Gough \& Scott, 2001; Hopkins \& McKeown, 2005; UNESCO, 2005), as both reject scientific measurement as pinnacle, embracing authentic forms of assessment and welcoming variety and iteration (UNESCO, 2005). Finally, ESD's attachment to high levels of engagement through problem solving, social interaction, application, reflection and emergent outcomes is indubitably correlated with both Eisner's approach as well as constructivism, a learning theory considered symbiotic to ESD. Attention paid to the process of learning is unmistakable in both Eisner's approach and ESD (Dale \& Newman, 2005).

To summarise, the scaffold provided by Tyler (1949) satisfied a gap where Eisner (2002) was more vague and flexible. Conversely, Eisner enhanced the course redevelopment model with his flexibility and creativity that Tyler lacked. In the model (Figure 1), the influence of the Tyler Rationale (Tyler, 1949) is most evident in the initial phases related to the identification and organisation of learning outcomes; specifically, the process provided for analysing sources of information related to student, society and subject and the screening of those sources through the educational philosophy and psychology of ESD. The remainder of the model, however, was chiefly influenced by Eisner.

\section{Implementing the model}

Once the model's structure was in place, the first author began the process of implementing the model, while the second author served as a peer debriefer, periodically reviewing the implementation process. During each phase of the process described below, the first author would meet with the second author to review the process and outcomes, which often resulted in adjustments to refine the implementation. The following discussion is organised by each phase of the process. 


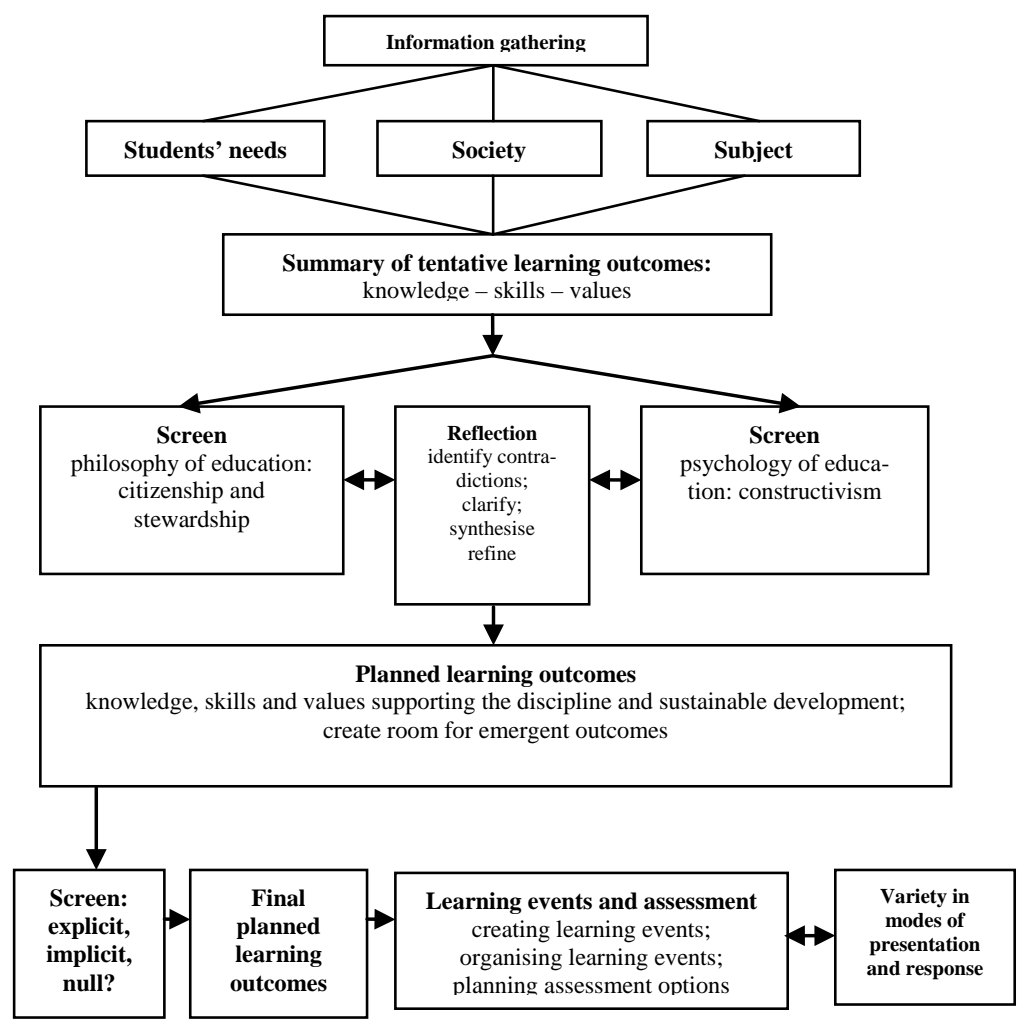

Figure 1. Course redevelopment model

\section{Information gathering for the needs of students, society and subject}

As the current project was to redevelop a single course and not an entire curriculum, a content analysis of highly credible literature was used as secondary data to answer to the needs of students, society and subject in lieu of primary data collection recommended by Tyler (1949). To aid in organisation of this literature, three common categories of outcomes, reflective of the ESD literature, were used as boundaries: knowledge, skills and values related to the specific course topic (product development) and sustainability. The researchers together identified four primary sources of literature for analysis, which were selected to provide a balance between priorities related to the specific course topic (product development), as well as those used to provide a broader perspective about sustainability and sustainable development.

First, meta goals for four-year baccalaureate programmes, published by the International Textiles and Apparel Association (ITAA) in 2008, which specify educational goals for undergraduate academic programmes in the U.S. These goals offer specific objectives about the knowledge, skills, as well as attitudes students should acquire while completing their undergraduate programme. These goals were utilised to speak for students' needs in the knowledge, skills and values categories. Second, Glock \& Kunz (2005) in the book Ap- 
parel Manufacturing: Sewn Product Analysis offer a precise list of knowledge, skills and attitudes that students should have to enter the apparel product development profession. This source was ideal as it is narrowly focused on the specific skills related to apparel product development, the subject of the course being redeveloped. This source enriched the ITAA objectives when speaking for students' needs for knowledge and values. Third, a literature review was organised to provide a framework for the key knowledge, skills and values that have been associated with ESD (Armstrong, 2011). As the primary goal of this study was to meet the needs of society sustainably, this body of work was utilised exclusively when speaking for societal needs related to knowledge, skills and values. Lastly, as the redeveloped course was related to product development and to be consistent with the ESD framework's call to reframe content for sustainability, a comprehensive comparative literature review of apparel design and product development contrasted with sustainable approaches was organised to identify key points on which the content in the course should be reframed for sustainability (Armstrong \& LeHew, 2011). This investigation included an exhaustive review of the apparel product development and design literature authored by TA academicians, and an extensive review of the literature regarding sustainable product development and design methods authored by a variety of academicians and industry practitioners from diverse disciplines. Both literature reviews were later published as theoretical projects.

As the current study utilised highly credible literature as opposed to collecting primary data about the needs of students, society and content, some assumptions were made about the nature of the outcomes found in these sources, differing somewhat from Tyler's (1949) prescriptions. Firstly, when perusing the aforementioned literature for educational outcomes, the first author focused solely on items related to the categories knowledge, skills and values pertaining to the course topic (product development) and sustainable development, the boundaries set in the case for learning outcomes. For instance, when surveying literature used to speak for students' needs, the researcher did not necessarily centre analysis on the psychological needs of students or any other needs falling outside the development of knowledge, skills and values. Tyler's (1949) work is considerably applicable to primary and secondary education and, therefore, includes concerns of a much wider scope about the needs of learners who are developing into adults; a lesser concern in the current study in higher education. Although some important psychological needs were likely to be met in the redeveloped course, it was categorically beyond the scope of this project to study them formally. Secondly, in the content analysis of the ESD literature used to speak for societal needs, the role of the current ecological crises was prominent as an explanatory maxim regarding contemporary life. Because this course was being redeveloped to better support sustainable development, a few other milieus could speak as poignantly to these needs as the planet's unsustainability. Responsively, the future was the primary consideration in creating educational objectives designed to aid learners in preparing for factors such as continuing evaporation and escalating cost of natural resources. 


\section{Summarising and screening learning outcomes}

Potential learning outcomes for the new course were gathered from the above literature based on their relevance to apparel product development, but also to the development of citizens and stewards, the primary purpose of ESD (Egan, 2004; Kevany, 2007). To organise these potential learning outcomes, the first author created three matrices, labelled knowledge, skills and values. Table 3 offers an illustration of one matrix used to organise potential learning outcomes related to skills across all bodies of literature. At this time, outcomes that seemed duplicative or highly correlated across the various types of literature were synthesised; while other outcomes were reframed. For instance, both the TA and ESD literature identify collaboration as an important skill for learners to develop. But, in an ESD context, collaboration is linked more intentionally to capacities like civic engagement and democratic dialogue. Thus, this was the first point in the course redevelopment process when the researchers began to see how ESD might reframe what the discipline says is important for learners, accomplishing both what is prised in the discipline as well as the goals of ESD. In addition, outcomes considered too comprehensive for a semester-long course were also edited down or eliminated. These key decisions were made during peer debriefing sessions with the second author.

Table 3. Summary of potential learning outcomes: skills

\begin{tabular}{|c|c|c|c|c|}
\hline & Students' needs & Students' needs & Society's needs & Content needs \\
\hline Source & ITAA $(2008$, p. 3) & $\begin{array}{l}\text { Glock \& Kunz } \\
\text { (2005, p. 112) }\end{array}$ & $\begin{array}{l}\text { ESD literature re- } \\
\text { view (Chapter 2) }\end{array}$ & $\begin{array}{l}\text { product development } \\
\text { comparative analysis }\end{array}$ \\
\hline $\begin{array}{l}\text { Tentative } \\
\text { outcomes; } \\
\text { skills }\end{array}$ & $\begin{array}{l}\text { identify and evalu- } \\
\text { ate issues of social } \\
\text { responsibility, } \\
\text { professional be- } \\
\text { haviour and ethics } \\
\text { related to the im- } \\
\text { pact of individual } \\
\text { organisational and } \\
\text { corporate decision- } \\
\text { making; } \\
\text { analyse and evalu- } \\
\text { ate issues related } \\
\text { to environmental } \\
\text { sustainability and } \\
\text { environmental } \\
\text { impact as they } \\
\text { relate to industry } \\
\text { activities and } \\
\text { processes; }\end{array}$ & $\begin{array}{l}\text { have a strong } \\
\text { teamwork orienta- } \\
\text { tion; } \\
\text { motivate team } \\
\text { members and other } \\
\text { associates to con- } \\
\text { sistently do their } \\
\text { finest work; } \\
\text { communicate in a } \\
\text { clear, direct and } \\
\text { persuasive manner } \\
\text { to executives, peers } \\
\text { and other associ- } \\
\text { ates; } \\
\text { focus on accuracy } \\
\text { and consistency of } \\
\text { details; } \\
\text { effectively manage } \\
\text { time and other } \\
\text { resources; } \\
\text { organise and priori- } \\
\text { tise work flow; }\end{array}$ & $\begin{array}{l}\text { skills for citizenship } \\
\text { and stewardship: } \\
\text { collaboration and } \\
\text { cooperation; gaining } \\
\text { buy-in (Jucker, 2002; } \\
\text { Egan, 2004; ACPA, } \\
\text { 2008; Svanström et } \\
\text { al., 2008); } \\
\text { conflict resolution } \\
\text { (Jucker, 2002; Egan, } \\
\text { 2004; ACPA, 2008; } \\
\text { Svanström et al., } \\
\text { 2008) and negotia- } \\
\text { tion (Kevany, 2007); } \\
\text { creative and imagi- } \\
\text { native problem- } \\
\text { solving (Jucker, } \\
\text { 2002; Egan, 2004; } \\
\text { ACPA, 2008; Svan- } \\
\text { ström et al., 2008); }\end{array}$ & $\begin{array}{l}\text { interdisciplinary } \\
\text { collaboration and } \\
\text { cooperation; } \\
\text { work concurrently } \\
\text { and iteratively; } \\
\text { technological compe- } \\
\text { tence; } \\
\text { forecasting } \\
\text { sustainability; prob- } \\
\text { lem-solving; } \\
\text { research and analysis } \\
\text { of sustainability } \\
\text { impacts of product } \\
\text { development proc- } \\
\text { esses; } \\
\text { selection of viable } \\
\text { solutions per impact } \\
\text { analysis; } \\
\text { backcasting; } \\
\text { risk analysis; }\end{array}$ \\
\hline
\end{tabular}


Sequel to Table 3.

\begin{tabular}{|c|c|c|c|}
\hline $\begin{array}{l}\text { demonstrate criti- } \\
\text { cal and creative } \\
\text { thinking skills; } \\
\text { identify and under- } \\
\text { stand social, cul- } \\
\text { tural, economic, } \\
\text { technological, } \\
\text { ethical, political, } \\
\text { educational, lan- } \\
\text { guage and individ- } \\
\text { ual influences on } \\
\text { industry issues; } \\
\text { use appropriate } \\
\text { technology to fa- } \\
\text { cilitate critical, } \\
\text { creative, quantita- } \\
\text { tive and qualitative } \\
\text { thinking within the } \\
\text { textile and apparel } \\
\text { complex; } \\
\text { communicate ideas } \\
\text { in written, oral and } \\
\text { visual forms using } \\
\text { appropriate tech- } \\
\text { nology; } \\
\text { function as team } \\
\text { members and lead- } \\
\text { ers within profes- } \\
\text { sional and cultur- } \\
\text { ally diverse envi- } \\
\text { ronments; } \\
\text { demonstrate the } \\
\text { ability to critique } \\
\text { one self and others } \\
\text { constructively }\end{array}$ & $\begin{array}{l}\text { use computer technol- } \\
\text { ogy and electronic } \\
\text { communications ef- } \\
\text { fectively to enhance } \\
\text { effectiveness of deci- } \\
\text { sion-making, present- } \\
\text { ing and reporting }\end{array}$ & $\begin{array}{l}\text { meaningful communi- } \\
\text { cation, civic engage- } \\
\text { ment, democratic dia- } \\
\text { logue (Kevany, 2007; } \\
\text { ACPA, 2008; Everett, } \\
\text { 2008; Svanström et al., } \\
\text { 2008); } \\
\text { social sophistication } \\
\text { (Eagan, Cook, \& Jo- } \\
\text { eres, 2002; Kevany, } \\
\text { 2007; Everett, 2008; } \\
\text { Kelly \& Fetherston, } \\
\text { 2008; Svanström et al., } \\
\text { 2008) and social action } \\
\text { (ACPA, 2008; Haigh, } \\
\text { 2008); } \\
\text { reflection and intro- } \\
\text { spection (Jucker, 2002; } \\
\text { Forum for the Future, } \\
\text { 2005; ACPA, 2008); } \\
\text { identify and adapt to } \\
\text { change; } \\
\text { systems thinking } \\
\text { (McKeown, 2006; } \\
\text { ACPA, 2008) and con- } \\
\text { textualise issues (Dale } \\
\text { \& Newman, 2005); } \\
\text { articulation of values } \\
\text { (Warburton, 2003) and } \\
\text { values-focused thinking } \\
\text { (Keeney, 1992; Sipos et } \\
\text { al., 2008); } \\
\text { visioning for the future } \\
\text { (Egan, 2004; ACPA, } \\
\text { 2008); } \\
\text { sustainability research }\end{array}$ & $\begin{array}{l}\text { communication } \\
\text { of environ- } \\
\text { mental features }\end{array}$ \\
\hline
\end{tabular}

Next, Tyler's (1949) screens, the educational philosophy and psychology became the primary mechanism for aligning the learning outcomes cohesively with ESD. The philosophical screen is a statement by educators about the values that underpin the purpose of the education, defined by ESD as preparing citizens and stewards for life on local and global plains: at home, at work and in the community. Citizenship implies rights and responsibilities inherent in community engagement and interests beyond the self, while stewardship connotes responsibility for present and future generations as well as the environment (Forum for the Future, 2005). Tyler recommends creating a concise statement for this phase of screening, which the researchers stated as:

The purpose of education is to prepare the learner for citizenship and stewardship in their local and global community. Educational learning outcomes designed for this end should emphasise interconnectedness in relationships with others and re- 
sponsibility for the environmental health and social justice for present and future generations.

Likewise, Tyler (1949) suggests writing a statement about the primary components of the preferred educational psychology, a set of conditions believed necessary for learners to learn. In an ESD context, high levels of learner engagement through problem-solving experiences that require inquiry, analysis, peer collaboration, application of course concepts and reflection on real experience are preferred. Instruction is broad in scope and requires the learner to challenge current paradigms. Also, the educator is a facilitator and collaborator, allowing the learner ample freedom to direct their own learning (Dale \& Newman, 2005; Ellis \& Weekes, 2008; Sipos et al., 2008). It is easily surmised that these conditions align most ideally with a constructivist epistemology. Therefore, the researchers prepared the following statement for the psychology screen:

The ideal conditions for learning are best described through a dialectical perspective of constructivism, which emphasises the construction of knowledge by the learner through social interaction in collaborative groups and with the instructor, consistently challenging the learner's previous stance. Educational outcomes designed for this end should emphasise imaginative problem-solving, collaboration and reflection.

Placed on index cards, these screens were used to analyse the potential learning outcomes gathered related to knowledge, skills and values. Using the philosophy screen, the researchers asked themselves questions like: How can Outcome $\mathrm{X}$ be used to develop a citizen or steward? How can Outcome X support sustainability? True to Eisner's (2002) characterisation of curriculum development, this phase of course redevelopment was highly intuitive. The practice of synthesising learning outcomes and insuring their alignment with this screen was highly iterative and heavily reliant on the researchers' judgment. Using the psychology screen, the researchers asked themselves questions like: How can Outcome $\mathrm{X}$ be developed by the learner? What action is required by the learner to develop Outcome X? The psychology screen was also useful later when formal learning outcome statements were to be generated, using action verbs related to a constructivist pedagogical method like explore, practice, critique and demonstrate. Most importantly, care was taken during this analysis to root out language incongruent with sustainability. For instance, TA's preoccupation with consumer wants, growth and profit were reframed to better support sustainability. Table 4 illustrates a summary of screened learning outcomes related to the skills category. Again, decisions to synthesise and refine these learning outcomes were reviewed by the second author and often amended during these peer debriefing sessions. 
Table 4. Summary of screened learning outcomes: Skills

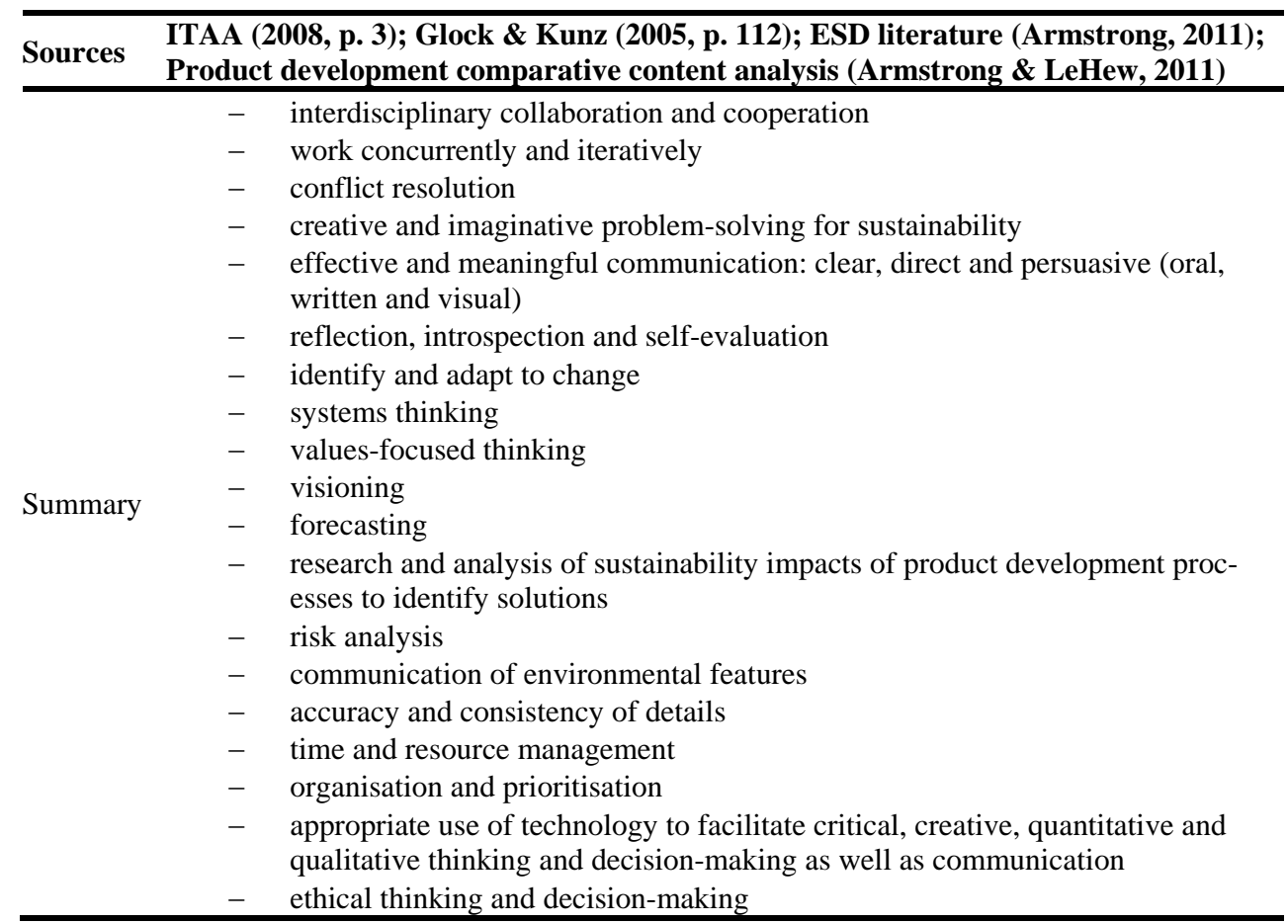

\section{Articulating planned learning outcomes: Explicit, implicit and null}

Upon completion of the above analysis, a summary of screened learning outcomes were evaluated for their appropriateness for the explicit curriculum, but attention was also paid to the implicit and the null. The researchers asked themselves: Are there desired outcomes which should be implicitly embodied in this course without being explicitly stated and measured? How might the implicit affect the explicit? What is missing from these outcomes entirely? The researchers found that most of the knowledge-related learning outcomes were appropriate for the explicit curriculum and could be communicated to students through the new course syllabus. Likewise, skills-related outcomes learning outcomes which were significantly focused on the goals of ESD, like working with others and critical thinking, were also explicitly communicated. Other outcomes remained implicit, alternatively embodied in the course implementation. For instance, a primary goal of ESD is to develop change agents (ACPA, 2008). Though not communicated explicitly on the new course syllabus, preparing students to be change agents in the apparel industry was clearly an underlying purpose of the educational experience. Likewise, outcomes related to professional standards like time management and attention to detail were left implicit. Many of the outcomes related to values that support sustainability were also left implicit, as the ESD literature makes clear, it is the articulation of values, not the indoctrination of them, thought critical to teaching for sustainability (Warburton, 2003). In terms of the null, the researchers discovered that what 
was chiefly missing from the TA curriculum was the illustration of alternative business models, as the current outcomes singularly focus on the mass production model only. Finally, the researchers took pause over the summary of learning outcomes and together began to condense and refine them into formal statements. The final planned learning outcomes for the redeveloped TA product development course, including knowledge, skills and values, are shown in Table 5.

Table 5. Summary of planned learning outcomes for a redeveloped course

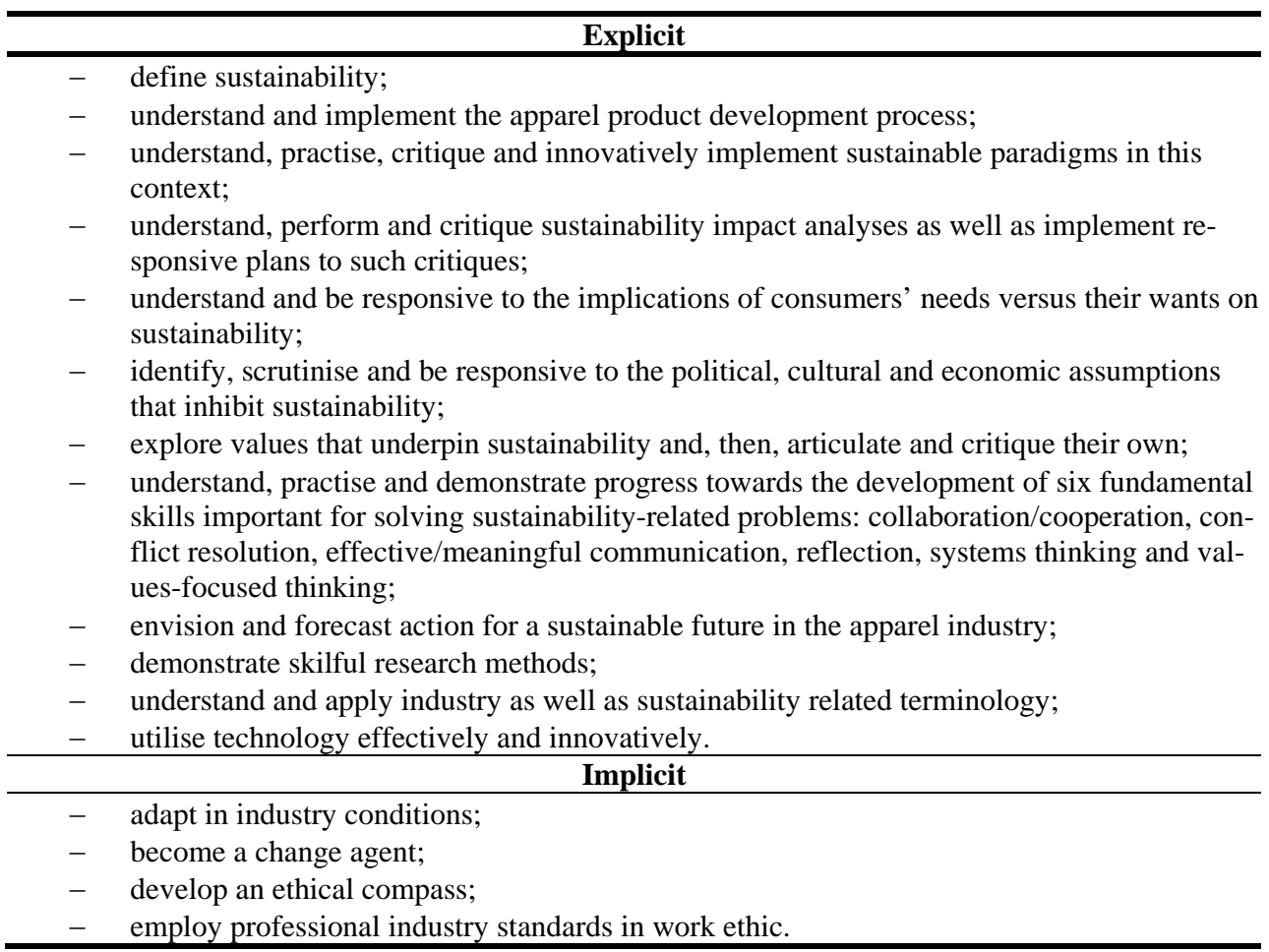

\section{Planning learning events and assessment}

Per Eisner's (2002) recommendation, assessment considerations were made concurrently while lesson plans, materials and activities were developed. The researchers found it helpful to first outline a chronological process of course modules that could be used to achieve the planned learning outcomes. In this particular case, it was helpful to simply use the product development process itself, which includes everything from materials selection, consumer and market research, marketing, technical design development to sourcing, distribution and retail strategy. A judgment was also made as to how much of that process could be learned in one semester.

Eisner's (2002) tenets of variety in modes of presentation and response as well as authentic assessment and loosely planned experiences which invite emergent outcomes were 
highly influential considerations in this phase. Complementary to both Eisner's philosophy and ESD, the epistemology of constructivism was also influential, designing events which focused on broad concepts and included social interaction, real experience, the exploration of multiple perspectives and required personal reflection. For instance, lesson plans were designed to be highly interactive and included a variety of media, including lecture, discussion, images or videos, activity and group critiques. When sustainability concepts were illustrated in a variety of different ways, learning about this complex concept was enhanced. Likewise, many course assignments were designed to offer learners several options for completion, empowering learners to choose how they wanted to present what they were learning, which increased engagement and investment in the project.

In sum, these were all chief considerations in crafting learning events and assessment methods for the new course. Prior to redevelopment, this course had followed a similar process, breaking up the steps of the product development process with a series of course assignments, ending on or around the sourcing phase. Thus, the first author began rewriting a similar series of assignments to better reflect the language and intent of sustainability and align with the pedagogical philosophies described above. The second author reviewed and offered criticism on each assignment.

Next, decisions were required as to when the ESD-related skills would be introduced and how. As the course was historically a collaborative capstone experience, the ESD skills would play a fundamental role in equipping learners for that experience and offer them a way to apply what they were learning. As values would underpin, not only project decisions, but also how the groups might navigate conflict, values-focused thinking was positioned to be introduced in the early phase of the course. Then, a series of collaborative training sessions were designed for the first two weeks of the course, incorporating the collaboration-related skills (collaboration, communication, conflict resolution). The ESD skill, reflection, was built implicitly into two reflective writings to be completed in the middle and end of the course. This would allow students to reflect on their learning and their use of the ESD skills. The last ESD skill, systems thinking, was planned for introduction midsemester, at the peak of decision-making, in which learners would be experiencing the most complex assortment of choices.

This decision-making process was admittedly a challenging, iterative, exhilarating and sometimes exhausting and required ingenuity, craftsmanship, imagination and intuition, true to Eisner's (2002) description of the process. Here, the peer debriefing meetings between the two researchers were immensely helpful for refining the plan and insuring a successful course implementation. Often, plans for early stages of the course were scrapped when it appeared unrelated to plans for the latter portion and vice versa. Indeed, balancing the need to integrate sustainability with apparel product development forced the most important outcomes to the top. The researchers often used guiding questions to refine the plan, like: What is the most important thing learner must learn in this course? Or, what is the most important thing learners must learn in this course that they will be unable to learn in other courses? The planned learning outcomes for the course, both explicit and implicit, compassed tough decisions. Sometimes product development content was removed to accommodate sustainability. At other times, content was added to transform traditional product development concepts with sustainable ideas. Although some previous course materials 
were useful, nearly all of the lesson plans, assignments, activities and assessment methods for the redeveloped course were created from scratch to ensure cohesion as well as alignment with sustainability. However, much of the literature gathered in the earlier phases became key sources for lesson plans, assigned readings and activities. Following is a description of the products that evolved from the final stages of the course redevelopment model.

\section{The semester project}

During this final planning phase, a report was published by Bennie, Gazibara and Murray, called Fashion Futures 2025 (2010), which was the result of expansive research among apparel industry and academic professionals about what the future of fashion might look like in fifteen years. The report was designed as a conceptual tool for apparel companies to strategise for the future, a strategy called "future proofing," used to insure the viability of long-term strategic plans, responsive to certain adversities like climate change, resource shortages and price hikes and dramatic demographic changes. The report hypothesises four potential scenarios responsive to these adverse trends, offering a window into potential outcomes for the future. Many of the sustainable design paradigms, already planned for course instruction, were referenced in the various scenarios. Thus, the report provided a powerful mechanism to stimulate imaginative thinking in light of sustainability challenges in the context of fashion.

The researcher decided to centre the new course on a hypothetical industry scenario in which a fictitious sustainable apparel marketer called Green Sweat, Inc. had gone belly up after attempting to enter the market using a sustainable platform. Students would play the role of product development employees whose expertise had been tapped to set the defunct brand on a more sustainable and viable path. Literature regarding miss-steps in sustainable strategy in the apparel industry was used to create a company dossier, describing the company's primary mistakes, which included both product-related as well as team-related shortcomings. Thus, students would use the report as a tool to future-proof their product development plan. Members of the student groups would carry real industry titles such as Marketing Director, Merchandise Coordinator, Head Designer, or Director of Sustainability and would be expected to play these roles in completing the course assignments. Likewise, the instructor would play the role of Director of Product Development and act as advisor, facilitator and collaborator on course projects.

The Fashion Futures report offered an opportunity to tweak the series of course assignments one final time to align with the report. Students would use the report to imagine, for instance, a consumer target market and a relevant product category. Students would work in groups to complete a series of group assignments for a specific future scenario outlined in the report; essentially, putting all the pieces of an apparel product development plan together over a semester period based on one potential vision of the future. The assignments included a consumer profile (demographic and psychographic descriptions), a product category scan (review of existing brand assortments), a theme and inspiration board, design concept and brief (development of actual designs and the explanation of relevant sustain- 
able design paradigms), a marketing dossier, a specification pack (technical design development and costing) and a sourcing plan (determination of manufacturing method and choice between developing a code of conduct or conducting a final analysis of their business model using a triple bottom line or stakeholder analysis). Historically, this course culminated in a group presentation to the class. But, since the focus of the semester project would be on imagining the potential future of fashion from different perspectives, the researchers decided to use this opportunity as an educational tool, not just for students, but the public as well, creating a final exhibit presentation of the students' work from the four scenarios. Exhibits are also considered an authentic assessment method.

Other forms of authentic assessment were used for group assignments; favouring techniques designed to prompt the student to explain their unique perspectives, justify their proposed solutions, demonstrate a collaborative effort and require the student to complete assignments with other assignments in mind, encouraging holistic thinking. Each group assignment was created to scaffold back to a previous assignment, insuring cohesion in the completed project, but also helping the student see a larger picture, the product development process and its impact on the ecosystem. A rubric of qualitative criteria for assessment was created for each group assignment, providing a mechanism for assessment of the planned learning outcomes for the course. Notably, the largest portion of each assignment's grade was consistently weighted in favour of imaginative problem-solving, critical thinking and authentic concept development, while other criteria such as professional execution and following the directions received far less weight. Further, consistent with Eisner's (2002) penchant for variety in modes of response (how the student communicates what they have learned), many group assignments offered students at least two ways, if not more, to complete assignments.

Explicit in the group assignments, was the incentive for critical and imaginative thinking about apparel product development and sustainability, encouraging students to cast off perceived limits and boundaries and explore What if? Responsively, assignments were written to allow groups to renegotiate assignment requirements based on what they were interested in exploring. For instance, for the marketing dossier assignment, students were asked to develop at least one piece of marketing material per group member as part of their marketing plan. But, this could be renegotiated in the event that a unique and innovative marketing strategy may require more labour and, thus, make the production of multiple materials less possible. Likewise, in the design concept and brief assignment, ample room was given for groups to create the number of looks that demonstrate the big idea of their line, rather than being shackled to a traditional twenty-four piece collection. In sum, assignments were kept structured enough to provide students direction in their conceptual process, but loose enough to prevent being boxed in by a traditional or prescriptive notion.

\section{Company training}

As part of the semester role-play, the ESD-related skills were incorporated into the course by way of a series of lesson plans at the beginning of the course, designated company training. This training would be presented to students, fictitious employees of Green Sweat, Inc., 
as important preparation for working through sustainability-related problems. An emphasis on conflict resolution was made, as this topic was often omitted from other professional development or management courses required by undergraduates in this TA programme. Historically, this course also held a reputation of generating ample conflict among student groups, so this tact was responsive to this need. A three class-period training programme centred on conflict resolution was developed. As such, training would likely prove a valuable framework for productive and effective collaboration. The book The Eight Essential Steps to Conflict Resolution: Preserving Relationships at Work, at Home, and in the Community (Weeks, 2004) provided the primary skeleton of the programme. The tenets used by Weeks aligned with the characteristics of the ESD-related skills, using similar language and approaches, which was invaluable. Additionally, scenarios were developed using real situations that had occurred in the course previously for students to work through together in class, applying the conflict resolution steps to determine approaches that could be used in those situations. Lastly, a final lesson plan surrounding the concept of democracy, considered fundamental to ESD, was used to reinforce and extend the ideas from the conflict resolution training with techniques, such as nominal group process and democratic dialogue and debate.

\section{Lesson plans and participation assignments}

Next, lesson plans and participation assignments related to course content were created. Central in these plans were shared work, discussion, opportunities for application and critique. Consistent with Eisner's (2002) philosophy of variety in modes of presentation (how ideas are communicated to learners), few lesson plans looked the same. Rather, the most important concept to be learned in the lesson was the spark to fuel the mode of presentation, with the chief consideration being student engagement. For instance, two class periods following the company training were designated as days to explore the future. The first class period would be a collective lecture in which groups would be assigned an article from the journal, The Futurist, about general global trends. Groups would be asked to read the article, determine the highpoints and relevance to the apparel industry and then share their findings with the class. Information gathered would be posted on a group wiki page, compiling useful information that all the students would utilise later when working on their semester projects. The Fashion Futures report would be introduced at the end of this lesson plan, as a way to then narrow future trends to the fashion industry. The second class period would utilise a workshop by Bennie et al. (2010; available at forumforthefuture.org) Fashion Futures 2025, in which groups could explore a day in the life of each scenario. Students would be broken into groups, assigned one of the four scenarios and asked a series of questions that might describe someone who lived in that scenario, such as: Where do you live? Where do you work? How do you get to work? What kind of apparel do you wear? Where do you shop? This information would be later used to develop the consumer profile assignment for the semester project.

Lesson plans related to sustainable design paradigms were also created. These lessons were designed to introduce the concept, allow students to apply it in some creative way and 
then critique its usefulness to the apparel industry. For instance, one lesson plan about Biomimicry introduced the concept and how it might relate to fashion design. Then, students would be asked to go out and photograph nature, developing an aesthetic palette they could later use in their design-related assignments. Upon return, they would be asked to critique the advantages and limitations of such a concept to apparel design. Another lesson plan, Design for Environment, introduced the concept of Design for X, a list of strategies that could be used to make manufactured products more efficient. Students would be given a garment profile, such as a wedding dress or swimsuit, with a list of its material contents and asked to redesign the garment for greater efficiency. Students would be asked to sketch out their ideas in groups and then share their new concepts with the class.

A number of lesson plans were designed around analyses fundamental to sustainability, such as triple bottom line, life cycle and stakeholder analyses. For instance, to help students learn how to use systems thinking, students would be required to read different articles about apparel brands that use sustainable strategies prior to the lesson plan. After the concept of systems thinking was introduced, the triple bottom line would be used to analyse the sustainable apparel market as a system. Lists would be created by students for social, environmental and economic issues reflected in the industry articles. Students would be asked to cross reference the triple bottom line with a SWOT (strengths, weaknesses, opportunities and threats) analysis during the discussion. Thus, students would identify SWOT elements under each triple bottom line heading. Upon completion, students could visualise a conceptual map of this system, seeing where social, environmental and economic dimensions of the system may conflict or reinforce each other.

Generally, lectures of static content were virtually absent. Lesson plans were more often characterised by mechanisms to trigger engagement such as discussion questions, games, group collaboration, creative brainstorming and application; the method chosen based on the concept to be learned. Lesson plans were often enhanced with entertaining video clips, such as lectures from Ted.com which often discuss abstract and highly innovative concepts related to design or sustainability, or unusual images of creative work related to design; both used to incite discussion and imagination. Implicit in these lesson plans was a high level of instructor-to-student and student-to-student interaction that made sharing ideas and information as well as labour more possible. This planned level of interaction is supportive of a constructivist approach to pedagogy, creating opportunities for mental contradictions that facilitate learning, but it also imposed a personal interdependency among the classroom community, supportive of sustainable development.

Reflective of Eisner's (2002) appreciation for the journey of learning, the researchers made an important decision regarding how the journey would be incentivised. The aforementioned semester project completed by student groups that comprised the product development plan only represented half of the total semester grade. The other half of the student's semester grade was derived from participation, which could be earned via two interrelated components: (1) 30\% of the course participation grade was determined by consistent attendance, quality engagement in the classroom, contribution to group work and a demonstration of a learning attitude and (2) the remaining $20 \%$ of the course participation grade would be derived from two reflective writings, discussed next, which prompted students to reflect on their own learning more deeply. As part of the former, a series of formal partici- 
pation assignments were created to support the lesson plans. For instance, one participation assignment required the submission of a power point slideshow of pictures taken for the Biomimicry lesson plan. The collective lecture conducted about the future became a formal participation assignment. Students were given an actual assignment description for these projects, for which they would receive formal feedback on their participation, another mechanism for assessment.

\section{Reflective writings}

Reflection has been identified in the ESD literature as an important skill for students to develop (Keeney, 1992; Forum for the Future, 2005; Howard, 2008). More importantly, student reflections are considered to not only enhance the learning process but also provide a valuable evaluation tool about how students experience their learning environment and how learning takes place (Kusnic \& Finley, 1993; MacGregor, 1993). As such, two reflective writing assignments were built into the course; one during the mid-term and the other at the close of the course. A template was created to explain each skill, to aid the student in understanding how these skills were defined and, thus, how they may evaluate themselves and reflect on their performance. During the reflective writings, students would be required to discuss their use of the collaborative and thinking skills as well as general learning insights that may have occurred. This assessment tool would hold students accountable for using their collaborative work to learn more about themselves and improve their performance.

\section{Teaching the implicit}

As discussed here in the development of lesson plans and course assignments, the explicit planned learning outcomes were given ample room to be changed, exceeded and transformed by students in their experience taking the course, an important expectation of Eisner (2002). But, central in all course activities was the implicit and, much hoped for, the development of potential industry change agents. The course was ultimately designed to empower TA students to make change, asking What if?, arming them with multiple perspectives, their own imaginative skill, their own ethical compass and the collaborative and cooperative skills to engage others in whatever their mission may be. Other implicit outcomes included the ability to navigate real industry expectations and conditions, such as the iterative, concurrent, interdisciplinary and collaborative nature of product development.

The course design reflected such conditions. Firstly, collaborative interdisciplinary teams were formed; creating student collaborative groups from both marketing and design students, while also designating unique responsibilities that characterised the management roles they played. Secondly, more than one group assignment was often being completed at the same time, prompting students to toggle between multiple activities, working on multiple issues concurrently. This required two-way communication between managers who were facilitating different pieces of different assignments, which ultimately, supported 
greater cohesion among assignments. Lastly, students found themselves in a situation commanding them to employ various professional standards, fundamental to the apparel industry, such as time management and attention to detail, even if these were not made explicit in the planned learning outcomes.

\section{Recommendations and conclusion}

Admittedly, the preceding descriptive case study was elaborate, but is nevertheless useful for illustrating the general process by which educators may integrate sustainability according to ESD. During this case study, the researchers were able to develop a process which addressed two major need areas: the need to empower individual educators to integrate ESD at the course level and the need to provide a mechanism to hold the educator accountable to ESD in the context of any discipline.

Though it may be unlikely that other educators may repeat this precise process, the model presents some key features found highly valuable during this conceptual process which may be customised based on the needs of the course and the educator, optimising the model's use. The following are some recommendations of how the above model could be utilised more succinctly.

- $\quad$ One should utilise the early portions of the model influenced by Tyler (1949) to reframe discipline-specific learning outcomes for sustainability. Key sources which describe the ESD framework, such as Armstrong (2011), McKeown (2006), or Forum for the Future (2005) are helpful resources for such.

- $\quad$ One should identify points where content may be enhanced for sustainability by comparing the discipline's literature on a topic to sustainability-related literature from other disciplines.

- $\quad$ One should use the portion of the model influenced by Eisner (2002) to develop learning events and assessment methods, using the pedagogical proclivities of ESD, like constructivism, to enhance learning about sustainability. See Armstrong (2011) for a discussion about the use of pedagogical practices that may be used to teach sustainability.

The model may also be used to holistically redevelop an entire curriculum, collecting primary data and working as a faculty team to transform an entire programme. Whatever the case, the course redevelopment model offers a structured process, which held the researchers in the current case accountable to ESD. Though curriculum development is, by nature, highly iterative and, in many ways, a trial-and-error endeavour, the model offers educators a mechanism for making sound decisions supportive of the educational philosophy and psychology of ESD. It also provides a conduit for producing a cohesive course plan to implement ESD, reframing discipline-specific content to align with sustainability.

Though institutional barriers to sustainability abound, the model may empower educators to act now, making transformational change at the course level. This may, in turn, catalyse larger systemic change. Finally, though a discussion about the findings related to the student experience in the redeveloped course during the larger exploratory case study is 
beyond the scope of this paper, it is instead the formal topic of other papers currently in progress. But, decidedly, according to students who participated in these studies, the course experience was distinct in its development of their understanding about sustainability, the development of their collaborative skills and the methods by which these capacities were developed.

\section{References:}

ACPA - College Student Educators International. (2008). Toward a sustainable future. American College Personnel Association. Retrieved from http://louisville.edu/student /about/ACPASustainabilityMonograph.pdf

Armstrong, C. M. (2011). Implementing education for sustainable development: The potential use of time-honored pedagogical practice from the progressive era of education. The Journal of Sustainability Education, 2, n. pag.

Armstrong, C. M., \& LeHew, M. L. A. (2011). Sustainable apparel product development: In search of a new dominant social paradigm for the field using sustainable approaches. Fashion Practice, 3(1), 29-62.

Bosselmann, K. (2001). University and sustainability: Compatible agendas? Educational Philosophy and Theory, 33(2), 167-186.

Bowers, C. A. (2001). Challenges in educating for ecologically sustainable communities. Educational Philosophy and Theory, 33(2), 258-265.

Calder, W., \& Clugston, R. M. (2003). Progress toward sustainability in higher education. Environmental Law Reporter, 33, 10003.

Cotton, D., Bailey, I., Warren, M., \& Bissell, S. (2009). Revolutions and second-best solutions: Education for sustainable development in higher education. Studies in Higher Education, 34(7), 719-733.

Creswell, J. W. (2007). Qualitative inquiry and research design: Choosing among five approaches. California: Sage Publications, Inc.

Dale, A., \& Newman, L. (2005). Sustainable development, education and literacy. International Journal of Sustainability in Higher Education, 6(4), 351-362.

de le Harpe, B., \& Thomas, I. (2009). Curriculum change in universities: Conditions that facilitate education for sustainable development. Journal of Education for Sustainable Development, 3(1), 75-85.

Egan, J. (2004). Skills for sustainable development. London: Office of the Deputy Prime Minister.

Eisner, E. W. (1967). Education objectives - help or hindrance? School Review, 75(3), 250260.

Eisner, E. W. (1998). The enlightened eye: Qualitative inquiry and the enhancement of educational practice. Upper Saddle River, NJ: Prentice Hall.

Eisner, E. W. (2001). What does it mean to say a school is doing well? Phi Delta Kappan, 82(5), 367-372.

Eisner, E. W. (2002). The educational imagination: On the design and evaluation of school programs (3rd ed.). Upper Saddle River, NJ: Merrill Prentice Hall. 
Ellis, G., \& Weekes, T. (2008). Making sustainability 'real': Using group-enquiry to promote education for sustainable development. Environmental Education Research, 14(4), 482-500.

Everett, J. (2008). Sustainability in higher education: Implications for disciplines. Theory and Research in Education, 6(2), 237-251.

Forum for the Future. (2005). Learning and skills for sustainable development. London: Higher Education Partnership for Sustainability.

Bennie, F., Gazibara, I., \& Murray, V. (2010). Fashion futures 2025. London, UK: Forum for the Future.

Foster, J. (2002). Sustainability, higher education and the learning society. Environmental Education Research, 8(1), 35-41.

Glock, R. E., \& Kunz, G. I. (2005). Apparel manufacturing: Sewn product analysis. New Jersey: Pearson Prentice Hall.

Gough, S., \& Scott, W. (2001). Curriculum development and sustainable development: Practices, institutions, and literacies. Educational Philosophy and Theory, 33(2), 13712.

Haigh, M. (2005). Greening the university curriculum: Appraising an international movement. Journal of Geography, 29(1), 31-38.

Haigh, M. (2008). Internationalization, planetary citizenship and Higher Education, Inc. Compare: A Journal of Comparative and International Education, 38(4), 427-440.

Hopkins, C., \& McKeown, R. (2005). Guidelines and recommendations for reorienting teacher education to address sustainability. Paris, France: United Nations Educational, Scientific, and Cultural Organization.

Howard, P. (2008). Ecology, phenomenology, and culture: Developing a language for sustainability. Diaspora, Indigenous, and Minority Education, 2(4), 302-310.

ITAA. (2008). Four-year baccalaureate programme meta-goals. Retrieved March 29, 2009, from http://www.itaaonline.org/downloads/ITAA_Four_Year_Baccalaureate_Pr ogram_Meta-Goals_2008.pdf

Jucker, R. (2002). “Sustainability? Never heard of it?” Some basics we shouldn't ignore when engaging in education for sustainability. International Journal of Sustainability in Higher Education, 3(1), 8-18.

Jucker, R. (2004). Have the cake and eat it: Ecojustice versus development? Is it possible to reconcile social and economic equity, ecological sustainability, and human development? Some implications for ecojustice education. Educational Studies Journal of the American Educational Studies Association, 36(1), 10-26.

Keeney, R. L. (1992). Value-focused thinking. Cambridge: Harvard University Press.

Kevany, K. D. (2007). Building the requisite capacity for stewardship and sustainable development. International Journal of Sustainability in Higher Education, 8(2), 107122.

Kuznic, E., \& Finley, M. L. (1993). Student self-evaluation: An introduction and rationale. In J. MacGregor (Ed.), Student self-evaluation (pp. 5-14). San Francisco, CA: JosseyBass.

Landorf, H., Doscher, S., \& Rocco, T. (2008). Education for sustainable human development. Theory and Research Education, 6(2), 221-236. 
MacGregor, J. (Ed.). (1993). Student self-evaluation. San Francisco, CA: Jossey-Bass.

Marsh, C. J., \& Willis, G. (2007). Curriculum: Alternative approaches, ongoing issues. Upper Saddle River, New Jersey: Pearson Prentice Hall.

Merriam, S. B. (1998). Qualitative research and case study applications in education. Hoboken, NJ: John Wiley \& Sons.

McKeown, R. (2006). Education for sustainable development toolkit. Retrieved from www.unesco.org/education/desd

Moore, J. (2005). Barriers and pathways to creating sustainability education programs: Policy, rhetoric and reality. Environmental Education Research, 11(5), 537-555.

Oliva, P. F. (2009). Developing the curriculum (7th ed.). Boston: Pearson Education, Ltd.

Orr, D. W. (2003). Viewpoint: Planning to learn. Planning for Higher Education, 31(3), 77-81.

Orr, D. W. (2004). Earth in mind. Washington, DC: Island Press.

Pinar, W. F., Reynolds, W. M., Slattery, P., \& Taubman, P. M. (1995). Understanding curriculum: An introduction to the study of historical and contemporary curriculum discourses. New York: Peter Lang Publishing.

Rees, W. (2003). Impeding sustainability? The ecological footprint of higher education. Planning for Higher Education, 31(3), 88-98.

Rode, H., \& Michelsen, G. (2008). Levels of indicator development for education for sustainable development. Environmental Education Research, 14(1), 19-33.

Sipos, Y., Battisi, B., \& Grimm, K. (2008). Achieving transformative sustainability learning: Engaging head, hands and heart. International Journal of Sustainability in Higher Education, 9(1), 68-86.

Stake, R. E. (1995). The art of case study research. Thousand Oakes, CA: Sage Publications.

Sterling, S. (2004). Higher education, sustainability, and the role of systemic learning. In P. B. Corcoran \& E. J. Wals (Eds.), Higher education and the challenge of sustainability; Problematics, promise, and practice (pp. 49-70). Dordrecht: Kluwer Academic Publishers.

Sterling, S., \& Scott, W. (2008). Higher education and ESD in England: A critical commentary on recent initiatives. Environmental Education Research, 14(4), 386-398.

Svanström, M., Lozano-Garcia, F. J., \& Rowe, D. (2008). Learning outcomes for sustainable development in higher education. International Journal of Sustainability in Higher Education, 9(3), 339-351.

Tyler, R. W. (1949). Basic principles of curriculum and instruction. Chicago, IL: University Chicago Press.

UNESCO. (2005). Contributing to a more sustainable future: Quality education, life skills and education for sustainable development. Retrieved from http://unesdoc.unesco.org/ images/0014/001410/141019e.pdf

Warburton, K. (2003). Deep learning and education for sustainability. International Journal of Sustainability in Higher Education, 4(1), 44-56.

Weeks, D. (2004). The eight essential steps to conflict resolution. New York, NY: Penguin Putnam. 
Yin, R. K. (1989). Case study research: Design and methods. Newbury Park, CA: Sage Publications.

\section{Correspondence:}

Cosette Armstrong, PhD, Oklahoma State University, 437 Human Environmental Sciences, Stillwater, OK 74078-6142. Tel: 615-495-9215. Email: cosette.armstrong@okstate.edu 